\title{
The Crisis in the Islamic Civilisation
}

\author{
Jan-Erik Lane \\ Fellow with Public Policy Institute, Belgrade \\ 10 Charles Humbert, 1205 Geneva
}

\begin{abstract}
The turbulence and political instability in several key Muslim countries have now global consequences, as thousands of Moslems leave their countries, because they cannot live or even survive there. This must constitute an enormous blame onto the Islamic civilization, harbouring more than 1 billion believers in the prophet Mohammed. Western countries bomb indiscriminately in Syria and Iraq, as a future protection against the new phenomenon of Islamic terrorism. It should be pointed out that the major co-ordination bodies in the Islamic civilisation - the Arab League and the Muslim Conference - have done little to stop the on-going civil wars and the horrific political violence. Similarly, the rich Gulf States offer no help for refugees, as they turn instead to the EU with its protection for human rights. How can we explain these civil wars within the Koranic civilisation? The ultimate reason is the rise of radical Islamic fundamentalism within the Sunni community during the $20^{\text {th }}$ century. And it is not going disappear soon. Could this civilisation implode from within in an unstoppable series of bombings, suicide killings and civil wars?
\end{abstract}

Keywords: Sunnis, Shias, Al Qaeda, ISIS, Boko Haram, Mawdudi, Qutb and Faraj, old Salafism, new radical fundamentalism, Wahhabism, Deobandi (India, Pakistan).

\section{INTRODUCTION}

A great crisis of belief in the world's large civilisation, viz Islam has resulted in the spreading of anarchy in the Middle East as well as in Northern Africa, setting in motions thousands of people eager to avoid the horrific nature of civil war. The crisis of Islam has had enormously negative consequences for many of the Muslim countries in terms of both human casualties as well as the destruction of physical assets. Unprecedented is the scope and ferocity of the civil war within the Muslim civilisation, as entire countries have become ungovernable, terrorised by rebels or militias supported by foreign intervention. The loss in human life and suffering of the Muslims is on an entirely new scale, resulting in a huge number of deaths from domestic violence as well as an unprecedented flow of emigrants towards Europe. Yet, there is no coherent response from the Koranic civilisation to quell this disorder and political violence.

Since the Muslim civilisation is together with the Christian one the largest in the world, the crisis in Islam has implications not only for Muslim countries but also for the West, harbouring more and more Muslims. It is not just only a simple matter of a youth bulk, young people without employment opportunity or having easy access to ever more lethal weapons furnished from abroad. It is not only the result of military intervention from Western powers, first Soviet Union in Afghanistan, then the Allied attack on Iraq and finally the Western support for the overthrow of Kaddafi. These violent military actions against countries in the Koranic civilisation resulted in dismal consequences and the collapse of the state in several Muslim countries. Yet, it is at the core of Islam that a confrontation of beliefs tales place between not only Sunnis and Shias but also between two Islams, one moderate and one fundamentalist.

\section{OLd An New CONFLiCTS}

The old conflict in the Muslim civilisation, namely Sunni against Shia, originating 632 after Christ with the prophet's death, has been immensely sharpened by the new conflict between moderates and fundamentalists. This simplification excludes several other conflicts that all have an ethnic element involved, such as the Kurdish struggles on various fronts, the clashes in North-western China, the conflicts between Jews or Christians and Moslems, etc. The century old struggle between Sunni and Shia has now worsened in several Muslim countries: Why is it seemingly unresolvable, resulting in so much political violence still today? The rise of the radical fundamentalism aggravates this religious cleavage in Islam. 
One may employ a simple $2 \mathrm{X} 2$ Table to illustrate the distinctions made by means of a few illustrative examples:

Table1. Groupings in Islam

\begin{tabular}{|l|l|l|}
\hline & Moderates & Fundamentalists \\
\hline Sunnis & Majority & Talibans, ISIS, Boko Haram, Al Qaeda, Al-Shabaab, Wahhabism \\
\hline Shias & Alevis, Ismailis, Zaydis & Khomeini, Twelvers \\
\hline
\end{tabular}

The Sunni-Shia tension is to be found in the Syrian civil war, the struggle in Iraq and in Bahrain, in the tension between the Gulf monarchies and Iran in Yemen. The emergence of radical fundamentalism as a major political force has occurred in Algeria, Tunisia, Egypt, Palestine, Syria, Iraq and Afghanistan. For instance, one of the radical groups, the Muslim Brotherhood (MB) is a branch of Sunni, opposed to both Shias and moderate Sunnis. The strong support for new Islamic fundamentalism is based upon a new interpretation of The Koran, which entail that there is somehow one and only one "correct" or "original" interpretation that must be institutionalised in state and society - islamisation.

\section{1. “Islamisation"}

The major fundamental change in Muslim civilisation, its beliefs and values, in the 20th century is the emergence of the idea that there is somehow $O N E$ Islam that can practiced one hundred per cent in all aspects of life. When combined with the old Salafist approach to The Koran, the chief approach of radical fundamentalism appears.

The old Salafism of Ibn Taymiyya (dead 1328) glorified the past of Islam - the age of the prophet. However, the golden period of the Islamic civilisation did not take place in early Arabia with its tribal practices. Instead, Islam flourished in the High medieval period and up to the Renaissance in all areas of social life: medicine, astronomy, mathematics, philosophy, trade, art, etc. The blossoming of Islamic civilisation was based upon openness to other cultures, free enquiry and sharp argumentative confrontation about basic beliefs.

The old Salafist view of the evolution of Islamic civilisation is to look backward, which is of course practically unfeasible in the period of globalisation when all the civilisations are interacting daily in various forms.

The new radical fundamentalism adds control, violence and force to the Salafist ideals. The people of Islam - Umma - is to be kept in a state and society, completely dominated by the ideals of ancient Islam, as if there really existed ONE Islam. The concept of jihad receives with a new interpretation as legitimate violence for defending a true Muslim society. "Political Islam" turns old Salafism into a totalitarian political philosophy with terrorism implications. It has been said about the founder of the MB, al-Banna that he wanted to restore the caliphate that had fallen in 1924 in Istanbul. However, the MB in Egypt soon developed a much more radical and comprehensive call for change of state procedures and social practices: Islamisation writ large.

\subsection{The Three New Major Theoreticians}

The chief theoreticians of modern Islamic Sunni fundamentalism - Mawdudi, Qutb and Faraj outlined a coherent utopia for a future Islamic state controlling a society structured in accordance with a very strict form of Islamic Law. Radical fundamentalism harbours differences, like e.g. severa in thel MB does not accept Wahhabism, as no one can come between the prophet and his community, neither Ali (Shia) or Muhammed bin Abd al-Wahhab (Saudi Arabia). Yet, these three scholars outlined a consistent new interpretation of the Koranic message: islamisation (Mawdudi), caliphate (Qutb) and offensive instead of defensive Jihad (Faraj). It has brought untold misery not only to people from other religious creeds, Shias, ethnic minorities but also the Sunnis themselves.

The new radical doctrine is based on one possible interpretation of the Koran as well as one selection of customs from the Hadith of the Sunna. Yet. In the history of Islam, there have been many interpretations of the Koran. Why would any interpretation be the "correct" one? There exists no criterion for selecting the "correct" practices in the Hadith, comprising an enormous amount of doings and sayings of the prophet.

"Islamisation" of state and society involves:

- One unique set of customs is valid in society, according to Sharia; 
- The state must be an Islamic state, oriented towards the enforcement of the Sharia;

- Religious leadership of government in the form of charismatic personalities, the caliphate;

- The use of violent means - jihad - to protect the Islam and to further Islamic objectives abroad, also with terror against Moslems.

The endorsement of physical violence has led massively to renewed forms of terrorism in the Islamic civilisation, practised by rebels, called jihadists. As a result, some of the Moslem countries are drowned in lethal rebel attacks on the state as well as on innocent civilians, often Shias but also other groups.

\section{RADICAL FUNDAMENTALISM}

New Islamic fundamentalism has several roots, where one does not preach exactly the same message, but these beliefs and values have come to the forefront as never before:

- Classic salafism;

- Saudi Wahabbism;

- Indian Deobandi.

What unites these different schools or theologies is a set of beliefs and values that now have more adherents than ever before, taught over and over again in the Koranic schools, madrasas, and universities including:

- Only Sunni Islam is true Islam;

- Shia Islam is faked Islam;

- Muslim societies can only thrive through "islamisation", meaning the literal application of Sharia, subjugation of women, caliphate rule, and jihad against intruders of Muslim societies or their collaborators in Muslim societies and elsewhere.

To understand the new radical fundamentalist Islam, it is vital to point out that Islam has always been is a mosaic of different beliefs, often with people fighting each other. Over the centuries, one finds moderate Islam, rational Islam, Sufi Islam, Shia Islam (several schools), etc. Fanatical Islam is put together in the 20th century by three most important scholars, namely: Mawdudi, Qutb and Faraj. Their teachings in books or pamphlets have turned the civilisation of Islam into a terrible civil war, the ending of which is impossible to predict. Whole countries have been left completely destroyed: Syria, Libya, Iraq, Afghanistan, Somalia, Mali and Northern Nigeria as well as Yemen.

As several Muslim countries have fallen into the set of failed states, one would be interested in searching for an explanation of anarchy within the Islamic civilisation. Religious and ethnic cleavages together with rebel fighting has turned countries like Libya, Mail, Nigeria, Somalia, Gaza, Syria, Iraq, Afghanistan and Pakistan into anarchic societies without functioning government. The lack of law and order also plagues Egypt, Bahrain and Bangladesh. Why is there now so much political violence in the Moslem world? The sufferings of ordinary Muslims from government breakdown and sectarian clashes as well as rebel fighting are such that many people have to leave and live elsewhere. The rise of Islamic fanaticism focussing upon Jihad is a crucial piece in this puzzle.

\section{Sunnis Versus Shias, Moderates against Fanatics}

The conflicts among Muslims are essentially of two types religiously, bypassing ethnic tensions:

- Sunnis versus Shias

- Jihadists versus moderate Sunnis and Shias.

The first conflict dates back to the origins of Islam, due to the complete lack of any political philosophy in The Koran. There is not a single word about the political future of the Islamic community - the Umma, when the prophet dies.

The Koran builds upon Jewish religion with the claim of being its ultimate culmination of the tradition from The Bible with its monotheism and the long series of prophets: Abraham, Moses, Jesus etc. It shares the Jewish opinion that Jesus could not have been the son of God, and it never mentions 
the real creator of Christianity, namely Paul. The Koran is the re-instatement of the Old Testament writ large plus the claim that Mohammed is the last of the prophets stating the final revelation of God to the humans. Without the Old Testament, no the Koran. But it says nothing about the world to come when the Prophet is no longer alive.

Mohammed ruled on the basis of charismatic authority, breaking tribal leadership prevalent on the Arabian Peninsula. This unique combination of political and religious power goes under the name of the caliphate. It has two profound problems:

1. How is the caliph to be chosen?

2. What are the basic rules of the exercise of his power?

There exists still no solution to these two basic problems of any rulership, one thousand and almost four hundred year after the Prophet. The outcome is the political instability all over the Muslim civilisation.

Over the history of Islam, the Koran has received different interpretations. Actually, the text war put together long after the death of the prophet and there exist competing collections of verses - the basic unit of the Koran. Whether the verses constitute the words of God has been a contentious issue with this religion, resulting in political violence in the 9th century. Although this position is generally regarded as blasphemy today, it is undeniable that the distance between the Salafist on the one hand and the rational interpretations on the other hand is large, to say the least.

This implies strictly the question of scepticism: How to identify the "correct" interpretation of the Koran? It leads to crucial questions about legal and political authority in the Muslim civilisation. One way out of the dilemma of widely different interpretations of a key religious text that attempts to establish the norms of society is to have some form of authority lay down the "correct" interpretation and then proceed to enforce it by all kinds of means.

The problem of interpretation received an early and, as it was thought, final solution with the figh: Islamic jurisprudence would codify what Islam stands for in a set of precepts that could not be denied nor neglected. However, this legalistic approach though highly influential upon later development after 800-900, did not success in arriving at consensus. Thus, there are 4 schools of jurisprudence within Sunni and another school within Shia. Their differences reflect the basic fact about a lack of underlying consensus in the Islamic civilisation, as Sunni schools differ from the Shia school and the Sunni schools differ among themselves as to doctrine and dogmas.

The close connection between religious dogma and political power became one of the hallmarks of Islam, as it never established an independent church, like Christianity. It was up to the successor of the prophet to maintain religious order and uphold its stated norms in society. Thus, the question of interpretation of the Koran became intimately linked with the successor problem: Who is to be the Caliph (Sunni) or the Imam (Shia)?

Islam does not contain like Christianity or the religions of India a much elaborated theology. The core of Islam is the set of 5 duties, nothing more. When they are respected, the believer will receive the salvation. This minimalist approach leaves much open to disagreement. And diversity of opinion on religious matters has become typical of Islam. One may ask why this diversity today is conducive to so much political violence within this civilisation, as religious tensions have subsided in the other civilisations of the world. One only has to bear in mind the enormous fighting within Christianity between Catholics and Protestants or the struggles between sects in Hinduism to recognize that there is nothing especially prone to conflict about the Koran. It is the interpretations of the text and the social practices based upon these interpretations that count

\section{RELigious ISSUES}

The Muslim civilisation holds a carpet of religious diversity where many groups are involved with a bewildering system of beliefs - just to mention a few:

- There are at least four kinds of Shiism: twelvers in Iran and Syria, seveners in Lebanon, Syria and India, fivers in Oman as well as the many Shiites in Turkey, called Alevis;

- Muslim brotherhood belongs under Sunni like ISIS and Al Qaeda;

- Sunni harbours old Salafism, new fanaticism as well as Islamic rationality. 
The main difference between Sunnis and Shias is the concept of tawdid, or oneness, which the Sunnis endorse but the Shias reject in favour of adding Ali to Mohammed as prophet.

In addition, it is true that there exist sharp differences between the moderates and fanatics. They range over a number of aspects of Islam besides the principal solution to the successor question, such as:

- Division of public and private;

- Division of mundane and sacred;

- Acceptance of modernisation.

It holds generally that average Sunnis tend to be more pragmatic than the average Shias in Iran. Thus, modernisation, secularism, the market economy and democracy is more supported in Sunni majority countries than in Iran, although this may only be a result of the Shia theocracy in Tehran that does not allow free and fair elections. Yet, this stylised picture of the Sunni countries as more moderate than the Shia ones is nothing but a simplification that hides complexity of religious opinions.

Religious beliefs are conducive to violence when they concern the distribution of valuable assets in scare supply. The control of these real assets - money, power, taxes, premises, land - is what human beings ultimately fight about, when the conflicts are not solvable through negotiation. Religious creed is a tool for exercising power over human beings, which is why people with different creeds collide when they happen to share the same territory and the same community. It is true that religious emotions may give the conflict between religious groups a special fervour and intransigence, but what is decisive is the access to the control over human beings.

However, issues in religious theology can only be resolved by argument, if ever. The most difficult questions that religious groups pose and answer differently concern matters that are metaphysical, such as:

- Is God one or three?

- Could Jesus be the son of both Joseph and God?

- Whom did Mohammed leave power to: a believer, his entourage? Or just his gender Ali?

- Is jihad a religious duty for all Moslems?

- Is Buddha a God or the God?

- Is Krishna really the incarnation of Vishnu?

- Can people receive luck by means of bhakti?

The list above about the mysteries in religion could be made much, much longer. It is all a matter about creed, or religious belief, not reason, or deductive or inductive argument. When people disagree about the answer to such metaphysical questions, they can employ the sword to find a speedy but always temporary solution, like Alexander at Gordon. But conflict cannot settle the matter, only offering a most short lived "solution". However, resort to the sword gives access to the real assets that people collide about: power, prestige, money, land, etc.

Religious purity is no doubt essential to some people with strong religious creed. However, it is one thing for these people to be able and have the right to practice this purity, and quite another matter to attempt to impose it upon other people with different minds.

\section{Religious Tolerance in Muslim Civilisation}

For an external observer, the tension between Sunnis and Shias appears like a relic from the past. Why can these two Muslim beliefs not co-exist? Since the ideas of the caliphate or the imam are long out of date, Muslim countries having some form of modern constitution, honouring religious tolerance, especially among its own Koranic communities.

During the so-called golden period of Islam during the medieval ages when there was great diversity of opinion, a solution to the question of reconciling faith with reason was formulated that could have befitted Islam much, if it has been widely endorsed, leading to religious tolerance.

The rise and growing strength of Muslim fundamentalism in an age of globalisation, modern economics and the triumph of the natural sciences is enigmatic. It is widely believed that Islam is 
somehow responsible for this global paradox, but it would be a fatal mistake to equate the religion of Islam, one of the three great monotheistic traditions, with unreason.

All the world religions have had to take a stand on the relationship between reason and faith: How to handle any conflict between the two? And all the great religions of the world today have devised a modus Vivendi between reason and faith, except Islamic fundamentalism. This is all the more astonishing as Islam was the first of the major religions to work out a tenable solution of how to respect faith while fully employing the faculty of reason and observation. Before Christianity came up with various solutions to this fundamental problem - with Thomas abs Aquino, John Locke and Baruch Spinoza - there was the theory offered by In Rushed or Averroes. It makes him the greatest of medieval philosophers.

The Decisive Treatise of Averroes sums up the entire debate about reason and faith in the Moslem civilisation with the emerging schools of philosophy and jurisprudence since the Koran was codified around 700 after Christ. Drawing upon the various contributions by inter alia Farabi, Avicenna and Ghazali as well as many other more like the Azelites, Averroes formulates his position in a few striking arguments about faith and reason. Muslims have to live with two meanings of the Book of God, the literal and the allegorical. So is the case with Jews and Christians, as stated much later by Spinoza. The only conclusion of the predicament of faith and reason is religious tolerance, as with Locke' Letter on Tolerance (1699).

The Koran like the "Sainte Bible" contains beautiful tales, which when not in accordance with scientific reason can only be told in their literal meaning as exactly that: stories, as first emphasize by Spinoza in Tractatus Teologico Politicus (1677). Yet, the first philosopher to realise the double truth faith and reason - was none other than Averroes from Marrakech.

The Sunni-Shia clash is a zero-sum conflict with no predictable outcome. This makes it meaningless, as there could only losers. The conflict between Sunnis and Shias has no victor or loser, but only human misery. It can go on for one hundred more years, but with no decisive outcome except human suffering. Why cannot Islam accept such a minimum of tolerance that Sunnis and Shias can live side by side, with their separate shrines?

\section{The Precepts of THE Koran}

What could be a better place to look for an answer than the Holy Book or the Book of God, viz The Koran. It states a few rules that are pertinent to the question:

- No Muslim may kill another Muslim;

- Muslims who are right guided will enter Paradise on judgement day;

- Muslim who turn infidels will suffer the same fate as all infidels, namely to burn in Hell;

- Muslims who have been misguided can repent their sins and perhaps receive God's mercy;

- A right guided Muslim accepts fully the consequences of the five duties.

One finds several places in the Koran where these principles are expressed. How they are to be interpreted depends upon who is to be considered a Muslim, what it entails to be seen as an infidel and what a rightly guided behaviour stands in details. Islam harbour diversity of opinions in relation to the coherence among the 5 rules above, resulting in major schisms and the formation of several sects. Thus, the Sunnis divide themselves in four schools of jurisprudence as well as in modernists and fundamentalists. The Shias constitute a most diverse lot, from Iranian and Iraqi fundamentalists with their own school of jurisprudence to modernists in e.g. Turkey, Syria and India. In addition, there is the group of Sufis among the Sunnis and Shias.

Now, in relation to the crucial question above, one must ask whether the Sunni-Shia civil war or the jihadists' attacks on Muslims can be motivated by these 5 rules of Islam. Salafists claim that Shiism is a blasphemy, because it violates ONENESS (tawdid), regarding Ali and his descending family as somehow a saint besides Allah. Jihadists under the influence of MB sharpen this rejection of Shiism as magic, but jihadism also looks upon moderate Sunnis and Shias as targets of political violence, aimed at islamisation.

The expansion of the concept of infidel to cover not only adherents of other religions but also Muslims with a different faith than Salafism was re-innovated in the 20th century by Mawdudi, Qutb and Faraj - the ideological fathers of Islamisation and radical massive terrorism. 
When a Moslem country adheres to the Islamic interpretation of these ideologues of fundamentalists, then peace and political stability is not feasible. They stand for an Islam that is as uncompromising with modernity and reason, as also Khomeini's Shia Iran. In Islam today, the French saying holds: Les extremes se touchent. And they extended to the scope of jihad fighting to include all kinds of infidels, Moslem or others, with deadly repercussions. Jihad as the hidden duty (Faraj) is allowed against anybody who opposes the islamisation of society (Mawdudi) or the state (Qutb). The political philosophy of radical fundamentalism is not derived from The Koran, but constitutes a 20th century dismal innovation in general Islamic philosophy.

In traditional Islamic philosophy with its great representatives during the medieval ages, the focus is upon the relationship between religious faith and reasonable belief. It covers a large range of issues about the origins of universe and life and the nature of human volition and destiny. Political Islam is a recent ideology with no basis in The Koran, emerging in the 20th century out of India (the Deobandi school), Pakistan and Egypt.

One is amazed to read about the number of Muslims volunteering to fight for the ISIS, as it offers a road map to death and humiliation. Young people may be attracted by the conception of a "martyr", but it is all make belief. When people die, they do not exist anymore, neither as spirits waiting for the resurrection nor as travellers to some "Paradise" in the Cosmos.

\section{Sharia LaW}

In presentations of the main features if Islamic Law, it is never underlined sufficiently that Sharia is basically private law. Islamic Law developed outside of Western law - Roman Law and Common Law - as the tool for Islamic jurisprudence (figh) to create a minimum of order in the Muslim Empire, growing rapidly after the death of the Prophet, both westward and eastward.

The new societies adhering to Islamic faith needed a fundamental set of rules for the behaviour of the Umma, i.e. the private life of the faithful concerning family, marriage, daily activities, business and commerce. Sharia Law provided this institutionalisation with its four schools of jurisprudence. None of them considered public or constitutional law at any length. It was simply assumed that the caliph or the iman would be a man rightly guided. When the Arab heritage was mixed with other non-Muslim traditions, the assumption remained that the khan, sultan or king (emir) would be right guided. Like Roman Law, Sharia Law spells out the implications of various forms of private contracts, which had to be respected ultimately due to divine sanction (Haegerstroem, 1953).

One may draw a parallel to Roman Law, which was also basically about private law, including criminal law. Corpus Juris Civilis did not regulate public power, which rested in the hands of an Emperor, who made law through "constitutions", meaning commands. The concept of constitutional law as restrictions upon the state emerged in the 16th century in Calvinist Europe. Several Muslim countries imported foreign constitutional law in the 19th and 20th centuries, but public law in Moslem countries never succeeded to establish political order, i.e. rule of law.

Rule of law captures perceptions of the extent to which agents have confidence in and abide by the rules of society, and in particular the quality of contract enforcement, property rights, the police, and the courts, as well as the likelihood of crime and violence." (http://info.worldbank.org/governance/ wgi/pdf/rl.pdf)

When public law started to develop, covering both constitutional law and administrative law, it targeted much what is now called rule of law or the Rechtsstaat (Reiss, 1991). It did not call for democracy or the universal franchise, because its goal was law and order under the legal framework. The rule-of- law regime offers constraints upon political power, whether be it the power of political leaders or that of bureaucrats. It counteracts a number of vices that political power often succumbs to, including:

- Arbitrariness;

- Corruption and embezzlement;

- Nationalisation of property;

- False accusations and unreasonable search and seizure;

- Detention without accusation;

- Politicised court rulings. 
Thus, a country which that honours rule of law upholds rules that restrain politicians and bureaucrats in an effort to promote the outcomes (a) - (f) that, which would be beneficial for both economic life and political liberty.

Where the rules of rule of law are observed, one would not always find democracy. In general it holds that democracy implies rule of law, but the opposite may not hold. Thus, the rule of law set of rules anticipated the democratic regime from a historical perspective, in both the UK and in Continental Europe (Lane 2011). And on the contemporary scene, one finds countries with considerable amount of rule of law, although they do not practise competitive democracy with free and fair elections that may be contested by any political party whatsoever.

A political regime that runs according to rule of law would satisfy a few conditions that constrain the exercise of political power. Rule of law entails that power is be exercised according to the following precepts concerning due legal process and judicial accountability:

- Legality (nullum crimen sine lege);

- Constitutionality (lex superior);

- Rights and duties: negative human rights (habeas corpus);

- Judicial independence: complaint, appeal, compensation.

The theory of good governance is based upon the hypothesis that a government adhering to these precepts will be more successful in enhancing socio-economic development than a government that fails to respect these principles.

Modern constitutions were basically imported from the West during the 19th and 20 centuries. But they most often were replaced by naked power or authoritarian constitutional documents. Even more important is the Islamic law lacks the fundamental notions of individual rights under the rule of law framework that became such a vital part of both English law (Common Law) and French-GermanSwiss Law (Civil Law). The institutional deficit in Muslim countries goes back to the so-called Golden Age, as neither the Prophet nor the jurisprudence created anything like constitutionalism. Islamic law deals with private law matters, theft, property, inheritance, marriage, religious matters like the wagf, etc. The worldly matters are left to chance with the restriction that the caliph, sultan, emir, king, imam, etc, must never be an infidel.

\section{Democracy And Political InSTABILITy In Muslim Countries}

One should make a clear distinction between political stability and democracy in relation the Arab Spring movement. Certainly, the groups involved strived for overthrowing authoritarian rule and military dictatorship, but hardly more than half of the people taking to the streets were democrats. A significant portion was made up of the Muslim Brotherhood, which searches for the re-creation of the caliphate. Thus, we have the following classification of Muslim countries:

Diagram1. Political Stability versus Democracies: Countries today with large Moslem populations

$\begin{array}{lll} & \text { Political Stability } & \text { Political Instability } \\ \text { Democracy } & \text { Turkey, } & \text { Bangladesh, Syria, } \\ & \text { Lebanon, Pakistan, } \\ & \text { Albania, Tunisia } & \text { Iraq, Nigeria, Mali } \\ & \text { Afghanistan, Libya, } \\ & \text { Somalia, Kenya } \\ & & \text { Indonesia, Mindanao } \\ \text { Dictatorship } & \text { Saudi Arabia, Qatar, } & \text { Egypt, Bahrain, Iran, } \\ & \text { Oman, Kuwait, UAE, } & \text { Algeria, Central African } \\ & \text { Jordan, Morocco, } & \text { Republic, Malaysia } \\ & \text { Brunei, } & \text { Kazakhstan, Kyrgyzstan } \\ & & \text { Uzbekistan, Tajikistan } \\ & & \text { Turkmenistan }\end{array}$


Diagram 1 shows that political instability and the lack of law and order characterizes much of the Muslim civilisation today. In the quest for political reforms in the Muslim civilisation, the focus has been exclusively upon the introduction of democracy, bypassing the horrors of political instability and neglecting the absence of law and order. The Arab Spring failed almost everywhere except Tunisia, simply unleashing political violence, anarchy and anomie. When an authoritarian regime falls in the Moslem World, then it is replaced by anarchy or anomie, i.e. warring rebel groups and fighting clans. The crucial importance of "clanism" for Arab societies and other Moslem states has never been adequately theorised. The sufferings of Muslims in countries with anarchy or anomie have become so huge that one cannot bypass that democracy efforts may fail and result only in political instability at an enormous price in lives, casualties and possessions. The worst is the warring rebel and "clanique" society.

Political stability as law and order may be identified with the notion of rule of law in the World Bank Governance Project. Government would face the task of upholding a set of minimum rights to due process of law, personal integrity and material possessions Figure 1 displays how this minimum kind of rule of law, not comprising the democratic regime, varies around the globe, according to the WB, mentioning a few Muslim states.

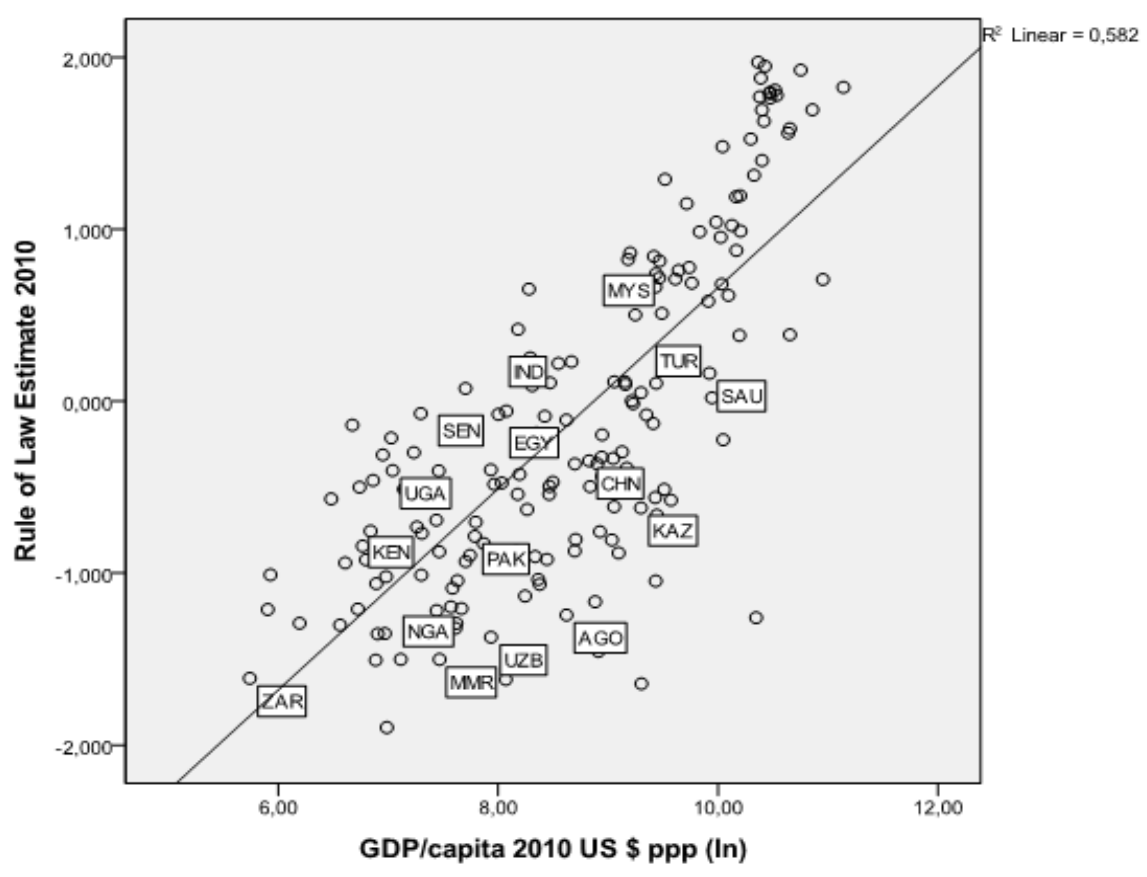

Fig1. Rule of Law: Political stability as law and order

Source: Sources: Kaufmann, D. A. Kraay, and M. Mastruzzi (2012) Worldwide Governance Indicators; World Bank (2012) World Bank Databank.

Political instability in several Moslem countries mean today not only day-to-day turmoil and assassinations, police brutality, lack of legal integrity, arbitrary court decisions, unlawful detentions, torture etc. It also involves something even worse, namely the new feudal order of conflicting rebel groups, heavily armed and most brutal. They fight government but also each other, using terrorist methods. In so far as the new anarchy and political instability in the Islamic civilisation is religiously motivated, it only makes the life of Moslems miserable. Figure 2 shows that the framework of rule of law is not well established in the Koranic civilisation.

The Koran is constitution free, with no mentioning of the idea of rule of law. The Koran only outlines a set of rules of the private behaviour of his community, especially regarding marriage, heritage and sex, with somewhat special rules for the Prophet. When these rules were worked out in the Islamic jurisprudence (Figh) by adding rules from the sayings and doings of the Prophet (Hadith), In no schools of Islamic jurisprudence does one find public institutionalism, as they all whether Sunni or Shia concentrate upon private behaviour. As a matter of fact, The Koran launches no political philosophy at all, which could have outlined the rules of political rulership in the Muslim civilisation. The Koran is one hundred per cent religion, with little philosophy and no politics in the sense of institutionalism. 


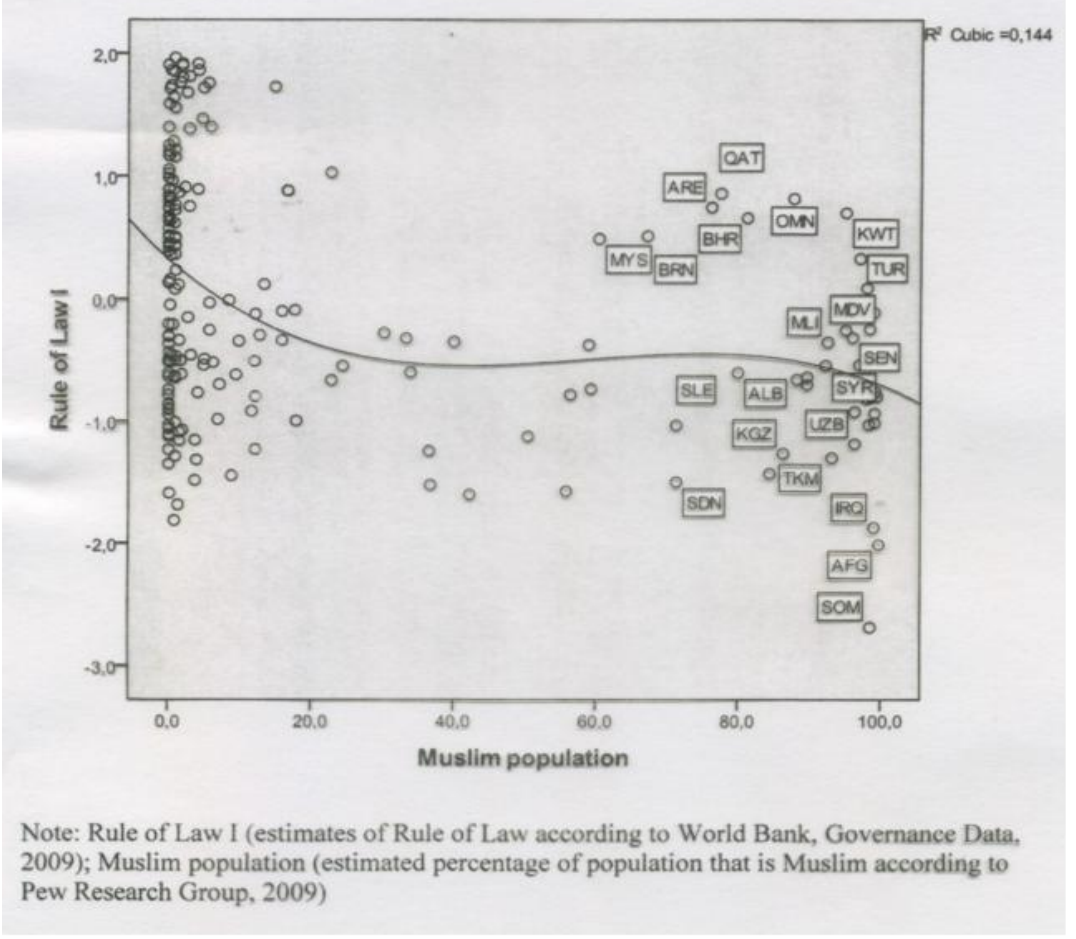

Fig2. Rule of Law in Muslim Countries

\section{Conclusion}

The amount of political violence has reached a level and intensity in the Muslim civilisation that hurts ordinary people in a manner that has no similarity what so ever in other global civilisations. It gives rise to the question about the religious cleavages in Islam and their implications for political violence and state stability. Jihadism introduces a so-called war of attrition into country, a most lethal phenomenon that involves fighting over a long time period until one party is exhausted.

It seems as if the Muslim civilisation may implode from inside, leaving numerous countries in civil war, anarchy, anomie, rebellion, attacks against innocents, women and children, looting by rebel groups and destruction of valuable material assets. Three responses have been suggested to the Muslim civilisation decline:

- Jahiliyyah: the concept for "ignorance of divine guidance" or "the state of ignorance of the guidance from God" or "Days of Ignorance. It would spell the demise of the Muslim civilisation and the end to all the hope among Moslems for a better life in human dignity.

- Western modernisation: democracy (Held, 1995). It has been tried in several Muslim countries, but only Tunisia seems to be successful. When coupled with the main religious cleavages it may even augment political violence and be cul de sac.

- Institutionalisation of legal-rational authority with government found upon rule of law.

Under a feasible rule of law regime with the recognition of The Koran, there is no need for so incredibly much political violence in the Muslim civilisation, leaving Muslims and other groups with peace, the hope of prosperity and religious co-existence of Sunnis, Shias and moderates as well as fundamentalists.

When the other civilisations in the world power ahead towards higher levels of well-being, parts of the Islamic civilisation destroys for itself, failing to protect the life and assets of its Islamic believers. The French would say: Ca sert a Quoi? Or The Romans would ask: Cui bono?

The search for the true Islam, as with the Salafists, or the Islamisation of state and society, as with the jihadists, is a meaningless effort. It has very negative consequences for the entire Muslim civilisation, resulting in endless political violence and the deaths of innocent civilians. The leadership in Moslem states and international organisation must start facing up to the task of making Moslems countries peaceful, tolerant and economically vibrant. 


\section{REFERENCES}

Roy, O. (2006) Globalized Islam: The search for the new Ummah. New York: Colombia U.P. Cooter, R.D. and Ulen, T. (2011) Law and Economics. New York: Pearson.

Lane, J-E. (2011) Constitutions and Political Theory. Manchester: Manchester U.P.

Fakhry, M. (2004) A History of Islamic Philosophy. New York: Columbia University Press,

Hobbes, T. (1982) Leviathan. London: Pemguin.

Hallaq (2010) An Introduction to Islamic Law. Cambridge: Cambridge University Press.

Kamali, M.H. (2008) Shari'ah Law: An Introduction. Oneworld Publications

Shabbir, (2007) The Quran and the Secular Mind: A Philosophy of Islam. London: Routledge.

Leaman, O. (2009) Islamic Philosophy: An Introduction. Cambridge: Polity Press.

The Koran (1995) London: Penguin.

Rapoport, Y. and Ahmed, S. (2010) (eds) Ibn Taymiyya and his Times. Oxford: Oxford University Press.

Winter, T. (ed.) (2008) The Cambridge Companion to Classical Islamic Theology. Cambridge: Cambridge University Press.

Adamson, P. and R. C. Taylor (2004) (eds) The Cambridge Companion to Arabic Philosophy. Cambridge: Cambridge University Press.

Al-Tamany, S.MS. (2014) Averroes, Kant and the Origins of the Enlightenment: Reason and Revelation in Arab Thought. London: I.B. Tauris.

Nasr, S.H. (2006) Islamic Philosophy from Its Origin to the Present: Philosophy in the Land of Prophecy. New York: State University of New York.

Calvert, J. (2010) Sayyid Qutb and the Origins of Radical Islamism. New York: Columbia University Press.

Held, D. (1995) Democracy and the Global Order: From the Modern State to Cosmopolitan Governance. Stanford: Stanford U.P.

Hägerström, A. (1953) Inquiries into the Nature of Morals and Law. Stockholm: Almqvist \& Wicksell.

Krisch, N. (2011) Beyond Constitutionalism: The Pluralist Structure of Postnational Law.

Klabbers, J., A. Peters and G. Ulfstein (2011) The Constitutionalization of International Law. Oxford: Oxford U.P.

Averroes, The Decisive Discours. http://people.uvawise.edu/philosophy/phil205/Averroes.html)

Roy, O. (2009) The Politics of Chaos in the Middle East. Oxford: Oxford U.P.

Fakhry, M. (2004) A History of Islamic Philosophy. New York: Colombia U.P.

Hallaq (2010) An Introduction to Islamic Law. Cambridge: Cambridge University Press.

Kamali, M.H. (2008) Shari'ah Law: An Introduction. Oneworld Publications.

Shabbir, (2007) The Quran and the Secular Mind: A Philosophy of Islam. London: Routledge.

Leaman, O. (2009) Islamic Philosophy: An Introduction. Cambridge: Polity Press

Rapoport, Y. and Ahmed, S. (2010) (eds) Ibn Taymiyya and his Times. Oxford: Oxford University Press.

Winter, T. (ed.) (2008) The Cambridge Companion to Classical Islamic Theology. Cambridge: Cambridge University Press.

Adamson, P. and R. C. Taylor (2004) (eds) The Cambridge Companion to Arabic Philosophy. Cambridge: Cambridge University Press.

Al-Tamany, S.MS. (2014) Averroes, Kant and the Origins of the Enlightenment: Reason and Revelation in Arab Thought. London: I.B. Tauris.

Worldwide Governance Indicators, in Kaufmann, D., Kraay,A. and M. Mastruzzi, (2010) "The Worldwide Governance Indicators: Methodlogy and analytical issues". World Bank Policy Working paper No 5430. http://papers.ssrn.com/sol3/papers.cfm?abstract_id=1682130

Nasr, S.H. (2006) Islamic Philosophy from Its Origin to the Present: Philosophy in the Land of Prophecy. New York: State University of New York. 
Calvert, J. (2010) Sayyid Qutb and the Origins of Radical Islamism. New York: Columbia University Press.

Ellis, M., Emon, A.M. And Glahm, B. (2010) (eds) Islamic Law and International Human Rights Law. Oxford: Oxford University Press.

Sayed Khatab (2009) The Political Thought of Sayyid Qutb: The Theory of Jahiliyyah. London: Routledge.

Malthaner, S. (2011) Mobilizing the Faithful: Militant Islamist Groups and Their Constituencies. Chicago: University of Chicago Press.

Jackson, R. (2010) Mawlana Mawdudi and Political Islam: Authority and the Islamic state. London: Routledge.

Adib-Moghaddam, A. (2014) A Critical Introduction to Khomeini. Cambridge: Cambridge University Press.

Wohlman, A. (2013) Al-Ghazali, Averroes and the Interpretation of the Qur'an: Common Sense and Philosophy in Islam. London: Routledge.

Ellis, M., Emon, A.M. And Glahm, B. (2010) (eds) Islamic Law and International Human Rights Law. Oxford: Oxford University Press.

Sayed Khatab (2009) The Political Thought of Sayyid Qutb: The Theory of Jahiliyyah. London: Routledge.

Malthaner, S. (2011) Mobilizing the Faithful: Militant Islamist Groups and Their Constituencies. Chicago: University of Chicago Press.

Jackson, R. (2010) Mawlana Mawdudi and Political Islam: Authority and the Islamic state. London: Routledge.

Adib-Moghaddam, A. (2014) A Critical Introduction to Khomeini. Cambridge: Cambridge University Press.

Wohlman, A. (2013) Al-Ghazali, Averroes and the Interpretation of the Qur'an: Common Sense and Philosophy in Islam. London: Routledge.

Wolrd Bank (2012) Governance Project: http://info.worldbank.org/governance/wgi/.

\section{AUTHOR BiograPHY}

Jan-Erik Lane, has taught politics and economics at many universities around the world. He has been member of many editorial boards of political and social science journals. He has published some 400 books and articles. In 1996 (and 2009), he received the Humboldt Award by the Humboldt Stiftung, receiving also a Lady Davis Fellowship at the Hebrew University in 2006 and also 2012, as well as honorary medals from Kairo University and the University of Qatar. He is a permanent resident in the Republic of Geneva and lives part-time in Myanmar. He has been full professor in 3 universities and visiting professor at many more. He is now a fellow with the Public Policy Institute in Belgrade. 